\title{
Should I Stay or Should I Go? Patterns of Party Switching in Multiparty Taiwan
}

\author{
Dafydd Fell
}

\begin{abstract}
Patterns of party switching in Taiwan have played an important role in the development and relative stability of its party system. In this study I aim to track key patterns of how politicians switched their partisan affiliation during the critical periods of party system change. I examine the level of party switching, where party switching was most prevalent, when switching was most common, and the most common types of switching since the advent of multiparty politics in Taiwan. Party switching is an important phenomenon in the development of party politics in Taiwan but thus far it has received surprisingly little systematic attention. This is the first comprehensive attempt to tackle this understudied topic. KEYWORDS: Taiwan, party switching, political parties, party systems
\end{abstract}

Compared to some of its EASt Asian neighbors, such as SOUth Korea and Japan, Taiwan's party system has been much more stable over the last two decades. Remarkably, the same two parties, the Kuomintang (KMT) and Democratic Progressive Party (DPP), dominate the party scene in 2012 as in 1986 . The year 1986 was particularly significant as it was the first election in which the KMT faced a genuine opposition party. ${ }^{1}$ Taiwan has not seen the kind of confusing wholesale party splits and mergers that characterized Korean and Japanese party politics for much of the 1990s and 2000s. Nevertheless, there have been periods where new Taiwanese parties emerged to challenge the mainstream parties and also times when politicians from the splinter parties moved back to the established parties. These patterns of party switching contributed to the country's fluctuations between dominant, multiparty, and two-party systems. 
Conventional wisdom suggests that party switching is not common and is largely restricted to newer democracies. However, recent studies show that the practice is far more common than expected and also features frequently in mature Western European democracies (Heller and Mershon 2005). Given the far-reaching potential consequences of party switching, it is perhaps surprising that it has not received greater attention in either the comparative party politics literature or studies focused on new democracies such as Taiwan. In a recent edited volume William Heller and Carol Mershon $(2009,4)$ note, "Despite its manifestation across countries and continents, party switching remains an understudied phenomenon. That is not to say that students of legislative and party politics have neglected it entirely, but rather that they have underestimated the breadth and depth of its significance."

In the Taiwan case, where the issue has received attention it has tended not to be the focal point of the research. For instance, Hsu Yung-ming (2006) has looked at party splits and mergers to explain Taiwan's changing party system, while I (Fell 2013) have argued that party switching can be viewed as a consequence of changing nomination practices. The scholar that has given the most attention to party switching (at least in English publications) has been Mikael Mattlin (2006, 2011). His studies have attempted to track and explain party switching at both the national parliamentary and grassroots level elections before and after 2000 . Therefore his research only focused on a limited number of elections before and after the first change of ruling parties.

Existing studies of party switching tend to look at the topic through a number of angles. A first challenge is how to define and measure patterns of party switching. Thus these kinds of studies consider what constitutes party switching, potential typologies, and the resources and standards for measuring the process (Heller and Mershon 2009, 8-10). A second challenge is how best to explain why politicians switch. Are they principally motivated by their own personal ambition for reelection, potential office perks, or their relationship with the party leadership? Another possibility is that their main driving force is ideological. In other words, politicians might be switching as a result of dissatisfaction with changed policy positions of their original party and the attractions of more desirable positions held by alternative parties. A classic instance of such a development occurred with the creation of the British Social Democratic Party by Labour politicians uncomfortable with their party's swing 
to the hard left in the early 1980s. Thus the party-switching literature is able to engage with the political science debate over whether politicians are mainly motivated by considerations of votes, office, or policy (Müller and Strøm 1999). As important as why politicians switch is the question of why most politicians do not switch even when they are highly dissatisfied with their party and there are alternative parties in the party system. The third and perhaps most important consideration of this topic are the consequences of party switching. Here much of the focus has been on the impact of party switching on the legislative party system, particularly patterns of fragmentation. However, this switching can also have a significant impact on both party and government policy positions, at least if the scale of switching is sufficient. We observed this in the 1990s in Taiwan when the departure of KMT politicians to form the New Party (NP) reduced resistance against Lee Teng-hui's attempts to reshape KMT and national government policies regarding national identity and China (Fell 2005a). Another dimension of the consequences theme is the impact of switching on politicians' subsequent electoral performance. For instance, Grose and Yoshinaka (2003) have found switching has had a negative effect on post-defection vote shares in the United States.

In this study I focus mainly on the first and third dimensions. I aim to track key patterns of how politicians switched their partisan affiliation during the critical periods of party system change. Key questions to be addressed include the following: (1) How common has party switching been? (2) Where has party switching been most intensive? (3) When has party switching been most common and have there been clear trends over time? (4) What have been the most common patterns of party switching-from party to party or between parties and independents? By pursuing these questions I hope to provide the first comprehensive examination of patterns of party switching in Taiwan.

I also reveal the significant consequences of party switching on Taiwan's party system. Unlike in South Korea and Japan, the lack of switching across ideological party lines has contributed to the relative stability of the Taiwanese party system. Party switching has affected the relative electoral fortunes of the major parties. In contrast to the loyalty of DPP politicians, high levels of defections away from the KMT served to undermine the party's electoral results for much of the period covered in this research. However, defections back to the KMT after 2004 contributed to its return to power in 2008. 


\section{Measurement of Party Switching}

The first task before answering these important questions is to determine what constitutes party switching for this study. Heller and Mershon $(2009,8-10)$ suggest two types of party switching according to direction, which are inswitches and outswitches. In the former case a politician adopts a formal party label after having another label, while an outswitch sees the abandonment of a party label without necessarily taking a new one. The outswitch is important in the Taiwanese case as it is quite common for party politicians to stand as independents or party rebels after failing to get official nomination. Often the party center will expel a politician for standing without endorsement, though in some cases they will later be allowed back. The line between party nomination and a rebel candidate is not always clear-cut, especially in the democratic transition period. Therefore the standard that I have taken is as follows: If the candidate is listed as an independent (usually KMT rebel or not nominated) they are taken as independents. However, where they are listed as KMT open nomination (i.e., they are allowed to run without formal nomination), they are taken as being officially nominated. ${ }^{2}$

In this article I use 1986 as the starting point, as it was the first election in which the KMT faced a genuine opposition party. Although the Tangwai can be regarded as the forerunner of the DPP, under martial law opposition parties were still banned as Taiwan was in effect a one-party state. ${ }^{3}$

Another way scholars have distinguished between types of party switching is by its impact on the number of parties. Thus, for example, Heller and Mershon (2009, 8-10) distinguish among (1) switching across existing parties, without change in the number of relevant parties; (2) fission, whereby an existing party splits into two or more new parties; (3) fusion, whereby two or more existing parties merge to create a new one; and (4) start-up, where party switches create a new party. At least in the Taiwan case we clearly have cases of switching across existing parties and start-ups. In addition there are a number of variants on the fusion type whereby a smaller party merges into an existing mainstream party. A case in point was when the Chinese Social Democratic Party (SDP) merged into the NP in 1993 but without the creation of a new party title.

In Taiwan there are a vast number of elected positions, from the national level down to the grassroots level of neighborhood or village chief; therefore I have had to be selective in my election level coverage. I focused on the career records of all politicians who stood for a 
relevant party in national-level elections. ${ }^{4}$ I take national-level elections as incorporating the Legislative Yuan, the National Assembly, and the presidency, and I also included data for city mayors, county magistrates, and the Provincial Assembly. I decided to be quite inclusive in terms of which relevant parties to examine; thus I examined data for all parties that nominated significant numbers of candidates over more than one election and had at least a minimum number of serious candidates (see Fell 2005b).

The main source I have used to locate politicians' party affiliation has been the listing on the Central Election Commission (CEC) online database for elections between 1993 and 2012. For the elections from 1986 to 1992 I made use of the newspaper election registration and result reports, mainly using the United Daily News (UDN) database. Two national-level elections that are not included in the CEC database are the final two National Assembly elections of 2000 and 2005. Including 2000 may seem controversial as the election was eventually aborted; however, party affiliation during this contest is an important window into trends in party switching at the outset of the DPP era (2000-2008). I relied on newspaper reports for the aborted 2000 National Assembly contest and the National Assembly's own database for 2005. Although I have only examined cases of politicians who have contested national-level elections, I also have taken into account the fact that Taiwanese politicians move both up and down the political ladder during their careers. Therefore I have also used candidate affiliation listing for other election types such as city or county council. In other words, where a politician has stood for a relevant party in a national-level election, I also tracked their career if they also stood at other lower levels. This means that I have a total of twenty separate elections over twenty-six years with which to locate party affiliation. ${ }^{5}$ This method is slightly different from that employed by most studies of party switching, which tend to just focus on one level of office, especially legislators who switched affiliation over a legislative term (Mattlin 2011, 101-128). However, my approach is more sensitive to changed affiliations since more cases can be picked up as politicians move up and down the political ladder.

The politicians examined in this study are first summarized in Table 1, which shows the number of politicians whose careers have been tracked is 1,984 . These are then broken down according to their party affiliation. Those in the KMT and DPP categories are politicians who stood for these parties in their first elections, respectively. 
Table 1 Politicians Representing Major Parties and Total Number of Politicians Who Switched at Least Once, 1986-2012

\begin{tabular}{lccc}
\hline Party & $\begin{array}{c}\text { Total Politicians } \\
\text { Tracked }\end{array}$ & $\begin{array}{c}\text { Total Politicians Who } \\
\text { Switched Parties } \\
\text { at Least Once }\end{array}$ & $\begin{array}{c}\text { Proportion (in \%) } \\
\text { of Politicians } \\
\text { Switching } \\
\text { Affiliations }\end{array}$ \\
\hline KMT & 1,014 & 343 & 33.83 \\
DPP & 612 & 143 & 23.37 \\
Blue & 195 & 76 & 38.97 \\
Green & 61 & 28 & 45.90 \\
Third & 102 & 23 & 22.55 \\
Total & 1,984 & 613 & 30.90 \\
\hline
\end{tabular}

Those categorized as Blue stood first for one of the following KMT splinter parties: People First Party (PFP) or NP. ${ }^{6}$ Those categorized as Green first stood for one of the following parties: Taiwan Independence Party (TIP), New Nation Alliance (NNA), or Taiwan Solidarity Union (TSU). Those categorized as Third first stood for other parties, such as the SDP, Labor Party (LP), or Green Party (GP). A first lesson here is that the number of KMT politicians contesting elections is far larger than that of their major rival the DPP. If we also factor in the politicians standing for the KMT and its splinter parties, then there is a ratio of approximately two candidates to one for the DPP and its splinter parties. It also shows the scarcity of politicians standing for election from alternative ideology parties, by which I mean parties not centered on Taiwan's national identity or Green versus Blue divisions. This does reflect the limits to political choice available to Taiwanese voters.

Next, Table 2 gives us a picture of the number of actual cases where party affiliation could be located for these 1,984 politicians. My dataset has captured a total of 5,177 cases. The example of Weng Chung-yun, the KMT politician from Chiayi County, can illustrate how the cases are calculated. During the period covered he stood for election for the KMT eight times, thus generated eight cases in which his affiliation could be located. We can see that the gap between KMT and DPP cases is actually narrower than that of politicians examined. This suggests that DPP politicians are more likely to have stood for multiple elections than their KMT counterparts. 
Table 2 Total Number of Cases and Cases of Switched Affiliation, 1986-2012

\begin{tabular}{lrcc}
\hline & & & $\begin{array}{c}\text { Proportion } \\
\text { of Switches } \\
\text { (in \%) }\end{array}$ \\
\hline KMT & Cases $^{\mathrm{a}}$ & Switches & 18.16 \\
DPP & 2,616 & 475 & 10.70 \\
Blue & 1,775 & 190 & 24.01 \\
Green & 479 & 115 & 28.99 \\
Third & 138 & 40 & 18.93 \\
Total & 169 & 32 & 16.46 \\
\hline
\end{tabular}

Note: a. The second column shows the total number of cases where politicians' affiliations could be located.

\section{Trends in Party Switching}

We can now begin to plot patterns of party switching between 1986 and 2012. The broad results are presented in Tables 1 and 2 showing the total numbers of switches and the proportion of switching cases. I located a total of 852 party switches over the period. This means that the overall probability of a politician switching is 0.16 . In other words, politicians switched partisan labels on approximately 16 percent of cases. Of course it is possible that these figures are slightly distorted due to certain politicians frequently switching party labels. Therefore I checked the number of politicians who switched at least once. Table 1 shows that almost 31 percent of politicians have changed affiliations at least once in their careers.

The next question is, who is more likely to shift party labels? Both Tables 1 and 2 reveal that party affiliation matters in switching. KMT politicians are far more likely to switch affiliation than their DPP counterparts. For instance, almost 34 percent of KMT politicians have changed affiliations at least once compared to 23 percent of DPP politicians. The KMT politicians switched in 18 percent of cases, compared to only 10 percent for the DPP. Therefore on almost a fifth of cases KMT politicians have switched party labels. However, politicians in the splinter parties showed the highest levels of party switching, with almost half of those in the Green category switching at least once. This gives us a picture of contrasting levels of party discipline, or perhaps loyalty, with the DPP showing by far the lowest level of defections. 
I wanted to see whether there is significant variation in geographical districts with a dataset that covers all of Taiwan. The largest metropolitan districts have moderate levels of switching, with Taipei City (15.5 percent of cases featuring switches) slightly below average and Kaohsiung (18 percent) above average. Kinmen and Lienchiang have by far the highest proportion of party switching at 31 percent of cases compared to the lowest in Yilan with under 10 percent. ${ }^{7}$ There does not seem to be a clear urban-rural difference in party switching. However, there are a few interesting patterns. If we examine the five districts with the highest levels of switching, it is clear that four of these cases have been highly dominated by the KMT and its allies, with almost no space for the DPP. The common feature of the locations with the lowest levels of switching is that they have mainly two-party competition and have thus had limited space for either splinters or independents.

The next question to consider is whether there is significant variation in when politicians have been most active in switching. Thus I have listed the top fifteen years for the numbers of party-switching cases in Table 3. It reveals that elections immediately following the party turnovers have featured the highest levels of party defections, such as 2001, 2002, 2000, 2008, and 2009. The year 2001 particularly stands out with 123 switches and 28 percent of cases that year featuring switches in affiliation. Although there is significant variation in annual levels of switching, Table 3 reveals that party switching has been a consistent phenomenon since the advent of multiparty politics in the late 1980s.

It is also worth examining whether there are particular periods when party switching was especially common. Time-series comparison can give a clearer picture of trends over time than looking at individual elections. Table 4 shows the numbers of party switches over eight legislative terms from 1986 to 2012 . It also suggests that party switching has been a constant feature of Taiwanese party politics regardless of era. Although the fifth term (1998-2001) has the highest level of party switching, the clear distinction is before and after 1998. In the first period from 1986 to 1998 party defections stood at approximately 13 percent of cases. However, in the post-2000 period the proportion of switching cases has tended to be approximately 22 percent. One surprising finding is that even after Taiwan's smaller parties collapsed in the advent of the new electoral system in 2008, the level of party switching has remained high in the most recent term (2008-2012). ${ }^{8}$ 
Table 3 Top Fifteen Years for Numbers of Politicians Switching Party Labels, 1986-2012

\begin{tabular}{lll}
\hline Rank & Year & Number of Politicians Who Switched Party Labels \\
\hline 1 & 2001 & 123 \\
2 & 1998 & 103 \\
3 & 2002 & 78 \\
4 & 1989 & 66 \\
5 & 2000 & 55 \\
6 & 2008 & 53 \\
7 & 2004 & 50 \\
8 & 1992 & 45 \\
9 & 2009 & 41 \\
10 & 2005 & 38 \\
11 & 1995 & 34 \\
12 & 2012 & 34 \\
13 & 1996 & 22 \\
14 & 1994 & 21 \\
15 & 2010 & 19 \\
\hline
\end{tabular}

Table 4 Party Switching over Eight Legislative Terms

\begin{tabular}{lccc}
\hline Term & Period & Switches & Ratio (in \%) \\
\hline 1 & $1986-1989$ & 73 & 13.20 \\
2 & $1989-1992$ & 58 & 9.22 \\
3 & $1992-1995$ & 72 & 14.23 \\
4 & $1995-1998$ & 142 & 13.26 \\
5 & $1998-2001$ & 179 & 22.26 \\
6 & $2001-2004$ & 129 & 22.13 \\
7 & $2004-2008$ & 104 & 17.96 \\
8 & $2008-2012$ & 95 & 21.16 \\
\hline
\end{tabular}

Table 4 also raises the possibility of comparing Taiwan's level of party switching with those of other countries. In countries such as Britain, Germany, the United States, or Germany less than 1 percent of legislators shift labels during a single term. However, Taiwan's levels of party switching are generally lower than those experienced in new democracies such as Brazil, Ukraine, or Russia, where incidences of switching tended to be over 30 percent. Even the supposed mature democracy of Italy has higher levels of legislative switching than Taiwan in its four parliamentary terms between 1988 and 2000 
(Heller and Mershon 2009, 11). ${ }^{9}$ In a cross-national collection of data on party switching, the case coming closest to Taiwan is actually the European Parliament with 16 percent of members of the European Parliament switching between 1989 and 1994.

We now have an idea of the years and political eras in which switching was most common. But what about the types of party switching? Who is moving and in what directions? In order to get a picture of this I have listed the most common forms of party switching in Table 5. The first thing apparent here is that the most common type of switching is what Heller and Mershon call outswitching from parties, or in other words, candidates from the major parties standing as independents or unnominated party rebels. However, such switches are far more common for the Blue parties, with by far the largest category switching from KMT to independent with 257 cases. Both the NP and PFP also suffered from significant losses to independents over their time as relevant parties. Though we see DPP-toindependent coming in as the second largest category, the rate of DPP politicians both standing as independents and switching parties is far lower than that of the Blue parties. The numbers switching back from independents to the main parties is also significant, but again it is particularly common for the KMT and its splinter parties. As for inswitching, or party-to-party switches, the key trend is that it is far more prevalent between the KMT and its splinter parties (Blues). The most common trends were KMT-PFP, PFP-KMT, NPPFP, KMT-NP, and NP-KMT. At the bottom end of the table there are some cases of inswitching/start-up between the DPP and Green parties, but the scale is far smaller than that seen in the Blue parties. In fact, the only category coming in the top fifteen is DPP-TSU, with sixteen such switches. One interesting finding is that although we tend to think of the TSU as a Green party allied to the DPP, it actually attracted an almost equal number of defectors from the KMT as it did from the DPP.

Another trend apparent here is the rarity of switches across the Blue-Green divide. The only major exception to this rule are the seventeen switches from the KMT to the TSU early in the DPP era (2000-2008). The sample I used found only four cases of switches from the KMT to the DPP. The most famous of these was Chen Ming-wen's switch in $2001 .{ }^{10}$ In the reverse direction from Green to Blue parties I only located one case of a switch from the TSU to the KMT and one from the DPP to the KMT. Readers familiar with Taiwanese politics may be asking about the cases of Chu Kao-cheng and 
Table 5 Most Common Types of Party Switching, 1986-2012

\begin{tabular}{llc}
\hline Rank & Switch Type & Number of Switches \\
\hline 1 & KMT-I & 257 \\
2 & DPP-I & 96 \\
3 & I-KMT & 77 \\
4 & KMT-PFP & 44 \\
5 & I-DPP & 43 \\
6 & I-PFP & 34 \\
7 & PFP-KMT & 27 \\
8 & NP-I & 24 \\
9 & PFP-I & 22 \\
10 & NP-PFP & 21 \\
11 & I-TSU & 19 \\
12 & KMT-NP & 18 \\
13 & KMT-TSU & 17 \\
14 & DPP-TSU & 16 \\
15 & I-NP & 13 \\
16 & NP-KMT & 13 \\
17 & TSU-I & 10 \\
18 & TSU-DPP & 8 \\
19 & DPP-NNA & 7 \\
20 & DPP-TIP & 7 \\
\hline
\end{tabular}

Cheng Li-wen. These two politicians did make the transfer from the DPP to Blue parties, but did so via independent status or other parties rather than directly. The first of these was Chu Kao-cheng, who was first elected for the DPP but after standing as a DPP rebel in 1989 went on to form the SDP. He then merged the SDP into the NP in 1993 and stood twice as an NP candidate. ${ }^{11}$ The second case involved the former KMT proportional representation legislator Cheng Liwen. She began her political career as a DPP National Assembly member in 1996; however, by 2004 she was standing as an independent in Kaohsiung and was elected as a KMT-nominated National Assembly member in $2005 .{ }^{12}$ Of course there are some puzzling individual cases, such as Hsu Chih-jen, who stood for the DPP in 1996 and then the NP in 1998 in Tainan County, or Huang Ta-ye, who stood for the NP in 1997 and then the TSU in 2001 in Miaoli. These cases are exceptional in that these politicians were moving from parties at opposite ends of the national identity spectrum.

With the data we have at hand we can now start to talk in terms of a series of minor and major waves in party switching that can also 
help to understand the key waves of party switching and developments in the party system. I have summarized the key trends in Table 6 , which shows the most important patterns of switching in the eight legislative terms. The vast majority of switches in the first two legislative terms during the period of democratic transition were outswitches from the KMT to stand as independents or KMT rebels. The table suggests how severe the problem of KMT discipline was in this period. In fact a number of the switches from KMT to independents in 1992 were by key founding figures in the creation of the NP, the first successful third party. ${ }^{13}$

During the first and second terms listed in Table 6 (1986-1989 and 1989-1992) a number of leftist parties emerged and nominated significant numbers of candidates in national- and local-level elections. These parties do not feature prominently in Table 6 as the vast majority of their candidates were getting their first taste of electoral politics and did not come from existing parties. There were a very small number of switches from the main parties to the leftist parties, such as Chu, who went on to form the SDP after leaving the DPP; Wang Yi-hsiung, who left the DPP to form the Labor Party; and Chang Yi-bang, who switched from the KMT to the Labor Party. In all these cases they were incumbent politicians who switched affiliation during their terms. Chu and Chang still hold the record of being the only leftist party politicians to be elected in Taiwan. ${ }^{14}$ That the vast majority of leftist politicians came from nowhere clearly played a major role in their electoral failures. In fact very few leftist party politicians even attempted to stand again after their initial defeat.

The first major pattern of inswitching between parties occurred in the 1992-1995 legislative term. The key shift was from the KMT to create the NP, a case of gradual start-up. In this term seven made the shift from the KMT to the NP, with seven more in the 1995-1998 term. The SDP's merger into the NP is also notable in the 1992-1995 term with five SDP politicians joining the NP. Thus party switching played a key role in the creation of the new party. During the mid1990s the NP had a major impact on the party system, winning significant Legislative Yuan, National Assembly, and City Council seats with a rough parallel of 13 percent of the vote and seat shares at the national level. The fact that it was recruiting established politicians in large numbers explains why it had a far greater impact on the Taiwanese party system than the leftist parties that emerged earlier on the scene in the democratic transition period.

The switching patterns in the next legislative term (1995-1998) suggest tensions within all three main parties. Table 6 shows some 


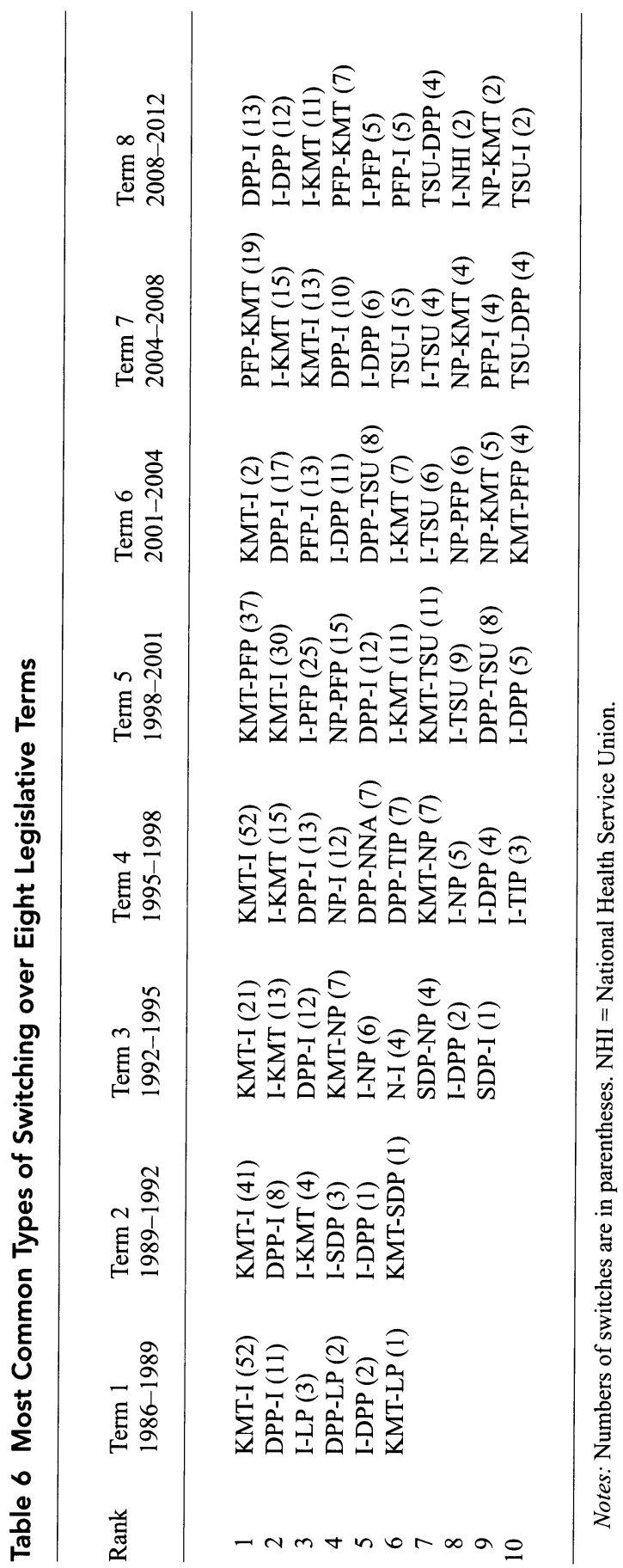


continuity in that there are still some switches from the KMT to NP; however, the majority of these switches from the KMT to the NP occurred in the first election (1996 National Assembly) in this term, after which such switches started to dry up. The large number of switches from the NP to independents also suggests that the NP was in crisis. Thus we can see why the 1998 election is viewed as the start of the decline of the NP. As usual there were KMT-to-independent switches (fifty-two). However, the most common switch pattern between parties in this period was from the DPP to more radical Taiwanese nationalist parties, the TIP and NNA, with a total of fourteen such cases. Nevertheless, the impact of this wave was lower than that of the NP, as out of these fourteen cases only two were successfully elected: Lee Ching-hsiung standing for the TIP in Kaohsiung and Hsu Tian-tsai for the NNA in Tainan City in 1998. The fact that there were two rival Green splinter parties both vying for votes and recruiting politicians also contributed to their short shelf life.

As we see in Table 6, the next legislative term saw the highest number of party switches, particularly in 2001. These switches contributed to the much more complex party scene of the early DPP era. The most common switches were toward the new PFP with thirtyseven joining from the KMT, fifteen from the NP, and another twenty-five from independents. By the 2001 election the NP had almost ceased to exist as the PFP poached many of its most electable candidates. When I interviewed the NP chairwoman Hsieh Chi-ta in 2001 she complained bitterly about how the PFP was enticing NP politicians to change sides. ${ }^{15}$ In 2000-2001 the PFP clearly was an attractive venue for ambitious politicians. Voters were also impressed, as it gained 20 percent of legislative seats in its first major election. Thus it performed better than the NP at its height and seemed to be threatening the KMT's status as the largest Blue party. The other start-up party to emerge at this point was the Taiwan Solidarity Union (TSU). As mentioned earlier, this party relied largely on recruiting politicians from both the KMT and the DPP.

There was more stability in the next legislative term (20012004). Instead of party-to-party transfers, switches from the KMT, DPP, and PFP to independents top the listing. Moreover, it appears that the momentum toward the PFP had slowed down. The most significant party-to-party switches were from the DPP to the TSU (eight). One notable trend was from the NP to the KMT, with five moving in this direction. In fact this was the largest party-to-party switch toward the KMT in my dataset to date. This move was part of a deal in which a group of NP politicians (re)joined the KMT and 
gained official KMT nomination and campaign support. ${ }^{16}$ These switches meant that the NP appeared to have effectively merged back into being a KMT faction. It is quite ironic that eleven years earlier it was the NP that was absorbing the SDP.

The revival of the KMT into Taiwan's leading party accelerated into the next legislative term (2004-2008) as nineteen PFP, four NP, and fifteen independents switched to the KMT in the run-up to the 2008 presidential and legislative elections. These transfers meant that even before the election it had already regained its status as the largest party in Legislative Yuan. The KMT and PFP made an arrangement similar to that between the KMT and the NP in 2004, which allowed PFP politicians to stand as KMT candidates. These transfers effectively meant that the PFP had, like the NP four years earlier, become almost a KMT faction. The low number of KMT switches to independents also suggests the attractiveness of the party. Therefore the trend of party switches in this term contributed significantly to the return of two-party competition and the virtual elimination of all the third parties in the 2008 legislative election. ${ }^{17}$

In the final term (2008-2012) there appears to be a continuation of trends from the seventh term. In other words, politicians continued to defect from the PFP, NP, and independents toward the KMT, though at a lower level than before. Similarly, politicians continued to defect from the TSU to the DPP. Both these trends reinforced the trend toward a two-party system. The one countertrend was the number of switches from independent to PFP in this term. This was part of the PFP's attempt to regain its status as a relevant party in 2012. At the time of writing it is uncertain what kind of switching trends to expect for the current term (2012-2016). It is quite possible that there will also be low numbers of switches in the near future as there are few electable politicians left in the smaller parties and electoral space for third parties, at least at the district level, appears lower than ever. ${ }^{18}$ However, the 2014 local elections offer an opportunity for the smaller parties to remain relevant.

\section{Serial Switchers}

Another way we can consider the issue of party switching is to look at the career record of long-term politicians who have multiple switch records. I have termed these as serial switchers. The politician with the reputation of Taiwan's serial switcher is of course Chu Kaocheng, who was discussed earlier. However, in my database there were eight politicians who, like Chu, had switched affiliations on 
four occasions. Two of these came from the top switching district of Kinmen. Another politician with a similar record of switching is Chu's former fellow partisan Yao Li-ming. Having first been elected as an NP legislator in 1995 in Kaohsiung County, Yao then stood as an independent (or NP rebel) in 1998 in Kaohsiung City. After a decade away from electoral politics, in 2008 he was on the party list for the Home Party (hongdang), which had emerged out of the anticorruption Red Shirts social movement of 2006. Next, in 2009 he stood officially as an independent but was jointly recommended by the Home Party and the NP in a legislative by-election in early 2009. Most recently he was named on the party list of the Taiwan National Congress. Although only featuring three switches, a more representative case is Lee Ching-hua, who started off as a KMT legislator elected in 1992, but within less than a year became a founding member of the NP in 1993. In 2000 he suddenly resigned as NP chairperson and joined the presidential campaign team of KMT rebel Soong Chu-yu that became the basis for the foundation of the PFP; he soon became a founding member of this party. Later when the PFP was on the decline he became part of the wave of defections from the PFP back to the KMT in the run-up to the 2008 elections. This is a common pattern in which KMT splinter party politicians eventually return to their original party.

Such patterns are far less common in the DPP, where standing as a rebel or switching to Green splinter parties is less easily forgiven. In my sample there were in fact only a handful of cases of DPP politicians who left to stand for another party and were allowed to return to the party. One such case was Chen Kuang-fu, who began his career as a Tangwai (1985), then DPP Kaohsiung city councillor, and then legislator in Kaohsiung. However, in 1998 he stood unsuccessfully for the TIP in the legislative elections. As the TIP fell into decline he returned to his original home of Penghu County, where he stood for the DPP on three occasions in local executive and legislative contests. A more successful but exceptional case was Hsu Tiantsai. Having won election as a legislator for the DPP in Tainan City in 1992, he was not renominated in 1995 and instead ran successfully as an independent. In 1998 he was reelected as a legislator for the NNA. His final switch came in 2001 when the incumbent DPP Tainan City mayor was embroiled in a corruption case. To resolve the problem the DPP allowed Hsu to return as its official candidate. Since then Hsu has remained in the DPP and won four successive elections. 


\section{Consequences of Taiwan's Trends in Party Switching for the Party System}

Having discussed in some detail the key patterns of party switching since the 1980s we can review some of the main consequences these patterns have had for party politics in Taiwan.

First, despite the moderate levels of party switching, these moves have not resulted in a chaotic party system. Instead there has been a clear logic to the patterns revealed in this study. The trends in party switching have thus contributed to the overall stability of the system. For example, the numbers of switches between the two main political camps have been negligible. Although there have been a large number of switches among the Blue parties, these again have not resulted in a transformation in the party system. In other words, though numerous KMT politicians switched to the splinter parties in the 1990s and post-2000 period, the majority of these splinter party politicians returned to the KMT between 2005 and 2010.

I have found that the most common type of changed affiliation has been outswitching from the relevant parties to independent. This phenomenon of rebel party candidates has been damaging for all parties, especially the KMT and its splinter parties. However, even here this pattern has contributed to party system stability because there is a large gap between those outswitching to independent and those being allowed to inswitch back from independent to the main parties. The DPP has long been the least willing party to allow former rebels to return to the fold, but it appears that this has increasingly also been the case with the KMT and other parties. In other words, there has been a squeezing of the space for independents, which has also served to enhance party system stability.

Party switching has been far more serious for the KMT and its allied parties than for the DPP. This has had important ramifications for the party system. The high levels of KMT defections have meant that there has been much more space for third parties to develop on the Blue side of Taiwanese politics. Thus, for instance, the two largest parties that have challenged the mainstream parties since the late 1980s have both split off from the KMT (the NP and PFP). The high numbers of switches from the KMT to independent and splinter parties (NP, PFP, and even TSU) all served to undermine the KMT's electoral performance between 1992 and 2004. These defections meant the KMT or Blue side of Taiwanese politics was crowded with candidates who divided the Blue support base. The most obvious example of this is the impact of the KMT rebel Soong Chu-yu on the 
2000 presidential election and how his PFP further divided the Blue votes in the period from 2001 to 2004 . What made party defections especially damaging for the KMT was that many of those defecting were experienced politicians with strong support bases. Thus defections served to undermine the KMT's human resources, at least until 2002. If the KMT had suffered a lower level of splinter party defections, it is likely it would have preserved its dominant party status longer.

After 2004 though, defections were to play a key role in the KMT's return to its status as by far the strongest party in Taiwan and thus to its landslide victories in 2008. The wave of defections from 2004 from the NP, PFP, and independents back to the KMT contributed to the return of a two-party system. Equally important was the way these switches served to unite the Pan Blue camp behind the KMT with a significant impact on the KMT's electoral performance.

In contrast, party defections have been far less severe for the DPP. Politicians have been less willing to stand as DPP rebels, knowing the chances of being elected or returning to the DPP are lower. Similarly, the DPP has suffered less than the KMT in defections to splinter parties. Looking at the cases of the TIP, NNA, and TSU, all illustrate this limited impact. Although the appearance of the NNA and TIP had an irritant effect on the DPP in 1998, it was far less than the effect of splinters on the KMT in 1995 or 2001. The key difference was that the DPP splinters failed to attract strong candidates to defect. The pattern was similar with the TSU in the early DPP era. As mentioned earlier the TSU recruited from both the KMT and the DPP. However, it was only able to recruit second-string DPP politicians who had no chance of nomination. In contrast, its ex-KMT politicians such as Hsu Deng-gong had more electoral support and experience. In short, patterns of party switching were highly beneficial to the electoral performance of the DPP and its development as a true competitor for national power.

A final area where we can see the impact of defections has been on what I have termed third parties. These are new parties that are not splinters from the KMT or DPP but base their party image on a different set of ideological appeals other than national identity. The clear pattern with candidates representing these parties is that with a small number of exceptions they came from nowhere. In other words, their candidates did not have prior experience in the mainstream parties or even as independents. Without an electoral support base these parties have a severe human resource deficit and thus have been at a 
disadvantage when it came to elections. Thus, for instance, the only successful third party candidates were the exceptions to the rule such as Chu Kao-cheng (SDP) and Chang Yi-bang (LP), both of whom had been originally elected for mainstream parties. ${ }^{19}$ This contributed to their struggle to make an impact on the electoral scene.

\section{Conclusion}

The topic of party switching has been neglected in Taiwan's political science. This study is the first comprehensive examination of Taiwan's party-switching patterns since the arrival of the first genuine opposition party in 1986. I have offered a picture of overall levels of partisan switching and variation according to political party and geographical location. I have also revealed the most common types of party switching and how party switching has changed over time. Despite the maturing of party politics and the institutionalization of the party system, party switching levels have actually risen since 2000 and even today remain high.

Despite the stability of Taiwan's party system, there have been significant numbers of party switchers. In fact the levels of party switching found in this study are quite high compared to most established democracies, though party switching has not been as chaotic and confusing as that seen in South Korea or Japan. I argue the patterns of party switching have actually contributed to the stability of Taiwan's party system. This stands in stark contrast to developments in Japan, where party switching contributed to the virtual disappearance of the largest opposition party, the Japanese Socialist Party, in the 1990s. In contrast, party-switching patterns served to strengthen the largest Taiwanese opposition party. Although switching has been more common among Blue parties, there has been an inherent logic to the patterns observed. Thus a large proportion of those who defected from the KMT to splinter parties have over time returned to their original party. Cases of party switching across the Green-Blue divide have been extremely rare. Another major difference between the two countries is that politicians from the KMT who defected have been far more likely than Japan's LDP defectors to return to the fold, which, again, has had a stabilizing effect.

This study of party switching also should be of interest to the broader field of party-switching studies. I present an extremely rich empirical examination of party-switching patterns that should offer the scope for comparative analysis. I have applied a slightly different 
method of tracking party affiliation from other works in that I also brought in candidate party status at levels of election other than national legislative contests. This has been more sensitive to picking up party switching, which is critically important in countries where politicians switch between different levels of elections.

Naturally this article has its limitations and reveals the scope for future research. For instance, it will be important to delve into the motivations for politicians to switch affiliations over time, which will require extensive fieldwork and examination of contemporary accounts of switching. Nevertheless, the patterns of party switching displayed in this study suggest a number of key explanatory variables to be tested. For example, it appears that party culture, party popularity, changes in party leadership, party policy positions, and nomination systems are all likely to be motivating forces behind decisions to switch affiliations. In the field of the consequences of switching it will be interesting to see whether switchers in Taiwan pay an electoral price for defection, as has been the case in the United States. If voters do punish switchers then why do politicians take the risk? A final element of the switching process that deserves attention are cases in which politicians switch electoral districts-a phenomenon noted in my database and one not yet touched upon in the broader party-switching literature.

Dafydd Fell is the reader in comparative politics with special reference to Taiwan at the Department of Politics and International Studies, School of Oriental and African Studies (SOAS), University of London. He is also the director of the SOAS Centre of Taiwan Studies. His recent books include Party Politics in Taiwan (2005) and Government and Politics in Taiwan (2011). He has a forthcoming coedited volume titled Migration to and from Taiwan (2014).

\section{Notes}

The author would like to thank Stephan Haggard and the two anonymous reviewers for their constructive suggestions for revising earlier drafts. I also am grateful for the research assistance from Jewel Lo and a research grant to support this project from the Faculty of Law and Social Sciences, School of Oriental and African Studies.

1. Whether we should call 1986 the first multiparty election is a controversial question. In 1986 the DPP challenged the KMT for the first time. However, at the time Taiwan was still under martial law, it was a one-party state, and the DPP was technically an illegal organization. On paper, there were other political parties under martial law, but these were known as 
flower vase parties, as they were essentially just KMT satellite parties designed to give the pretense of a multiparty system.

2 . This practice of open nomination was especially common in the democratic transition period and still occurs occasionally in the case of the KMT where it is unable to settle on one candidate in a single-member district and allows for free competition between two KMT politicians. It is most common in very safe KMT seats such as Miaoli where the DPP stands little chance even if confronted by a divided KMT. Moreover, open nomination is listed as officially nominated in the Central Election Commission database.

3. The term Tangwai (meaning outside the party) refers to opposition politicians standing for election who were not KMT members during the one-party state era.

4. It should be noted that I only included cases where politicians stood for at least one relevant party. Thus politicians who only ever stood as independents were excluded from the analysis.

5. I have also located affiliation and switching cases in a number of other years in which by-elections were held.

6 . The terms Blue and Green camps became popular in the post-2000 period. Blue is used for the KMT and its allies as this is the main color in the KMT's party flag. Similarly Green is the main color in the DPP's party flag.

7. Due to the limited number of cases, I combined Kinmen and Lienchiang into one category.

8. In 2005 Taiwan approved constitutional revisions that replaced the Legislative Yuan's old multiple-member district single nontransferable vote electoral system with one consisting of seventy-three single-member districts, six aboriginal seats, and thirty-four party list seats. Voters have two votes, with one for the district candidate and the second for their party preference. The party list votes are then distributed proportionally to parties gaining at least 5 percent of the vote.

9. This paragraph is based on a comparison with data in Heller and Mershon (2009), "Introduction," Table 1.2, 11.

10. At the time Chen was a KMT legislator but defected to the DPP to be nominated as its candidate for the Chiayi County magistrate.

11. He was later expelled by the NP and then stood twice unsuccessfully as an independent.

12. Some readers familiar with the Taiwan case may well be shouting out, "Why did you not include Su Ying-kui or Lee Yung-ping?" Again, both started out as DPP politicians and later joined the KMT and/or the PFP. However, neither stood as a DPP candidate, so neither was picked up in the database search.

13. The best examples were Wang Chien-hsuan and Jaw Shaw-kong.

14. Chu was elected for the SDP in 1992 and Chang won election for the Labor Party in Kaohsiung City Council in 1989. Wang Yi-hsiung failed in his bid for reelection under the Labor Party banner in 1989.

15. Interview, Kaohsiung, August 2001. 
16. In reality the KMT was quite selective in terms of which of these $\mathrm{NP}$ recruits it actively supported. For example, Lu Li-kang received little help from the Kaohsiung KMT party branch.

17. The only third-party candidate elected in 2008 was a PFP candidate in an aboriginal district, though he later had his legislator's status canceled due to a vote-buying case halfway through his term.

18. I appreciate that this point could be challenged in light of the limited revival of both the TSU and PFP in the 2012 legislative elections. However, they were almost all elected under the proportional representation party list rather than in regular districts.

19. Another such case is Kao Meng-ting, who though elected for the GP in 1996 in Yunlin already had a strong support base and close links to political society. In fact he was expelled from the GP just a year after being elected.

\section{References}

Central Election Commission Elections Database. http://db.cec.gov.tw/ (accessed May 14, 2013).

Fell, Dafydd. 2005a. Party Politics in Taiwan. London: Routledge.

. 2005b. "Success and Failure of New Parties in Taiwanese Elections." China: An International Journal 3, 2: 212-239.

- 2013. "Impact of Candidate Selection Systems on Election Results: Evidence from Taiwan Before and After the Change in Electoral Systems." China Quarterly 213: 152-171.

Grose, Christian, and Antoine Yoshinaka. 2003. "The Electoral Consequences of Party Switching by Incumbent Members of Congress, 1947-2000." Legislative Studies Quarterly 28, 1: 55-75.

Heller, William, and Carol Mershon. 2005. "Party Switching in the Italian Chamber of Deputies 1996-2001." Journal of Politics 67, 2: 536-559.

- 2009. "Introduction: Legislative Party Switching, Parties, and Party Systems." In Political Parties and Legislative Party Switching, ed. William Heller and Carol Mershon, 3-28. London: Palgrave Macmillan.

Hsu, Yung-Ming. 2006. "Splitting and Making Parties: Analysis of Party Reconfiguration in Taiwan." East Asia: An International Quarterly 30, 1: 7-26.

Mattlin, Mikael. 2006. "Party Opportunism Among Local Politicians After Taiwan's Power Transition." East Asia: An International Quarterly 23, $1: 68-85$.

- 2011. Politicized Society: The Long Shadow of Taiwan's One Party Legacy. Copenhagen: NIAS Press.

Müller, Wolfgang, and Kaare Strøm, eds. 1999. Votes, Office or Policy? How Political Parties in Western Europe Make Hard Decisions. Cambridge: Cambridge University Press.

National Assembly database. www.na.gov.tw/ch/repre/ReprePreview.jsp (accessed May 14, 2013).

United Daily News database. http://udndata.com/ (accessed May 14, 2013). 